\title{
The Role of Organizational Culture in Establishing Employee Engagement through Work Attitude at PT. Sapta Sentosa Jaya Abadi
}

\author{
Irwanto Sahat Wijaya Sibagariang1, Yeni Absah², Isfenti Sadalia² \\ ${ }^{1,2}$ Master of Management Study Program on Postgraduate School of University of Sumatera Utara
}

Corresponding Author: Irwanto Sahat Wijaya Sibagariang

\begin{abstract}
PT Sapta Sentosa Jaya Abadi is a company engaged in the plantation sector which is currently focusing on developing the quality of human resources, because the role of human resources is very vital in the production and quality of Fresh Fruit Bunches and Crude Palm Oil. However, company have problems in HR management related to Employee Engagement problems, it is indicated by the low score of Employee Engagement, especially those at the non-managerial level. PT Sapta Sentosa Jaya Abadi has made various efforts in building Employee Engagement, among others, by cultivating corporate values in order to form a strong organizational culture in the company. Based on this phenomenon, this study aims to see and analyze the influence of Organizational Culture on Employee Engagement through Work Attitudes as an intermediate variable at PT Sapta Sentosa Jaya Abadi. The research methodology used is Path Analysis. The results showed that Organizational Culture has a positive and significant effect directly on Work Attitudes; Organizational Culture has a positive and significant effect directly on Employee Engagement; Work Attitude is directly proven to have a positive and significant effect on Employee Engagement; and Organizational Culture through Work Attitude indirectly has a positive and significant effect on Employee Engagement at PT Sapta Sentosa Jaya Abadi.
\end{abstract}

Keywords: Organizational Culture, Work Attitudes, Employees Engagement, PT Sapta Sentosa Jaya Abadi

\section{BACKGROUND}

The topic of employee engagement in human resource management (HRM) is often discussed and discussed, both in academia and practice. Basically, employee engagement is the attachment of employees to the company where they work. This attachment is shown through positive behavior, namely being productive, complying with all regulations and also having an emotional sense of the company (Noe, et al, 2014). The concept of Employee Engagement is widely studied because based on the research results of several studies and also a survey of HR consulting institutions, it shows that Employee Engagement has a positive and significant impact on the contribution of company productivity.

As a company that has been established since 2004, PT Sapta Sentosa Jaya Abadi has an internal survey of its employees' Employee Engagement. The results of the pre-survey conducted from 2018 to 2020 show that the level of engaged employees for managerial and nonmanagerial levels is different, there is a higher level of non-managerial level employees than managerial levels. Managerial employees are employees with the positions of Foreman, Supervisor, and Manager. Meanwhile, non-managerial employees are those with the level of position, clerk, operator, harvester, and helper. 
Irwanto Sahat Wijaya Sibagariang et.al. The role of organizational culture in establishing employee engagement through work attitude at PT. Sapta Sentosa Jaya Abadi.

A study conducted by Wernel et al (2011) shows that employees who show employee engagement also show positive work attitudes, whereas disengaged employees show negative work attitudes so that it has a bad influence on other employees. Work attitude is a collection of feelings, beliefs, and thoughts held by employees about how to behave about work and the organization (Kaswan, 2015). Employees who have a positive work attitude also show positive performance, so this is relevant to employees who are engaged in the company. In line with Employee Engagement, the work attitude of employees at PT. Sapta Sentosa Jaya Abadi as a whole also did not show a positive category.

One of the studies on organizational culture in shaping engaged behavior was conducted by Prahara and Hidayat (2019) where the results of research conducted found that a positive work culture was able to increase the level of engaged employees. The formation of corporate values carried out by PT. Sapta Sentosa Jaya Abadi, among others:

1. Conduct training and seminars on company values

2. Conducting social activities in the form of Values Champion so that employees can directly apply the company's values not only in the world of work, but also outside the world of work.

3. Evaluating the application of company values through appraisal or employee conditions.

Many employees only know the company's values, but do not make it a work culture. They just read the company values every morning before work, but don't know what they mean. Regarding this matter, the personnel of PT. Sapta Sentosa Jaya Abadi stated that this phenomenon is true. The company's goal is to instil company values so that it becomes a positive work culture so that employee engagement and job satisfaction problems can be answered. However, management efforts have not shown optimal results.

\section{Organizational culture}

Shein (2005) said organizational culture is a pattern of basic assumptions created, discovered or developed by a particular group as it learns to deal with problems of external adaptation and internal integration - which have worked well enough to be considered valid and, therefore, to be taught to new members as the correct way to perceive, think and feeling in relation to the problem at hand. Robbin, Judge and Breward (2018) state that organizational culture is shaped by the values adopted by the company, where these values become work guidelines and guidelines for activities for all employees. Corporate values are the accumulation of actions and beliefs that serve as guidelines for the founders of the company.

\section{Work attitude}

Work attitudes are a collection of feelings, beliefs, and thoughts that people hold about how to behave today about work and organizations, attitudes are more specific than values and are not permanent because the way people perceive and live their work often changes over time (Kaswan, 2015). Work attitude is an employee's assessment (both affection, emotion and cognition) on the working conditions faced compared to what he has done in the organization.

\section{Employee Engagement}

Problems that are often faced by companies are workers who are not fully involved in their work or are often said to be "half", where this is workers are not one hundred percent of the total at work, there is a sense of laziness, time corruption, unprofessional, often mixed up with problems personal. Employee Engagement measures the totality of workers at work.

Noe, et al (2014) define worker involvement as the totality of workers in their commitment to work and the company. The extent to which workers assess the importance or not of work is in line with worker involvement. Schermerhorn, et al 
Irwanto Sahat Wijaya Sibagariang et.al. The role of organizational culture in establishing employee engagement through work attitude at PT. Sapta Sentosa Jaya Abadi.

(2010) stated that employee involvement is a strong positive feeling or integration with the organization. Meanwhile, Armstrong (2014) defines employee involvement as an expression of workers both physically and emotionally towards their work.

Armstrong (2014) states that there are 3 (three) elements in the formation of employee involvement: Commitment, The extent to which employees demonstrate commitment to the company both rationally and emotionally. Motivation, the extent to which a valuable assessment of the work and or company. Organizational Citizenship Behavior, this dimension refers to the extra performance of employees, in the sense of doing their work outside of what was ordered and or what is the work target. Of course, the main job or the main job of the worker is not neglected, OCB arises because the employee is able to complete the main job well so that he voluntarily does other work without disturbing the main job.

\section{Conceptual framework}

As described in the introduction as well as theoretical studies, that work attitude is a predictor of organizational culture formation as research conducted by Pieters, Zyl and Nel (2019). The results of research conducted by Prahara and Hidayat (2019) and Brenyah and Oubisa-Darko (2017) show that a strong organizational culture is related to employee engagement in a company. the results of this study support the assumption of correlation used in the study. This correlation assumption is described as a conceptual framework.

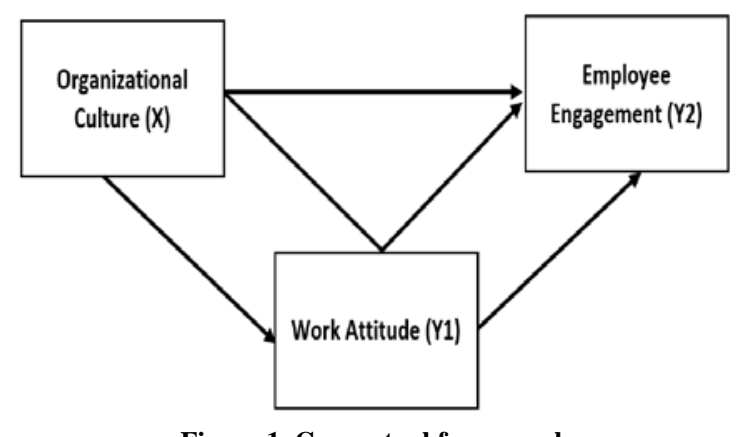

Figure 1. Conceptual framework

\section{Hypothesis}

H1-1: There is a direct positive and significant influence of Organizational Culture on Work Attitudes at PT. Sapta Sentosa Jaya Abadi.

H1-2: There is a direct positive and significant influence of Organizational Culture on Employee Engagement at PT. Sapta Sentosa Jaya Abadi.

H1-3: There is a direct positive and significant effect of Work Attitude on Employee Engagement at PT. Sapta Sentosa Jaya Abadi.

H1-4: There is a positive and significant indirect influence of Organizational Culture on Employee Engagement through Work Attitudes at PT. Sapta Sentosa Jaya Abadi.

\section{RESEARCH METHOD}

The design used in this study is correlational analytic, which is a type of research carried out with the aim of detecting the extent to which variations in a factor are related (correlated) with one or more other factors based on the correlation coefficient (Sinulingga, 2017). The population in this study were all nonmanagerial employees at PT Sapta Sentosa Jaya Abadi who had worked for at least 1 year, as many as 630 people. In order to represent the entire population, the research sample was drawn as a representation of the research population. Based on the slovin formula, the number of samples determined with a critical value of $10 \%$ for 630 people working population at PT Sapta Sentosa Jaya Abadi obtained a total sample of 85.77 or 90 people. The technique for taking the sample is simple random sampling. Data analysis technique in this research is Path Analysis with two approaches: Inner Model and Outer Model. While the data processing method used in this study is Partial Least Square - Structural Equation Modeling (PLS-SEM) using the SmartPLS application (v 2.3.8). 
Irwanto Sahat Wijaya Sibagariang et.al. The role of organizational culture in establishing employee engagement through work attitude at PT. Sapta Sentosa Jaya Abadi.

\section{RESULT AND DISCUSSION Hypothesis test}

Table 1. Direct Effect

\begin{tabular}{|l|c|c|c|c|c|}
\hline & $\begin{array}{c}\text { Original } \\
\text { Sample } \\
(\mathbf{O})\end{array}$ & $\begin{array}{c}\text { Sample } \\
\text { Mean (M) }\end{array}$ & $\begin{array}{c}\text { Standard } \\
\text { Deviation } \\
\text { (STDEV) }\end{array}$ & $\begin{array}{c}\text { T Statistics } \\
([\mathbf{O} / \text { STDEV|) }\end{array}$ & P Values \\
\hline $\begin{array}{l}\text { Organizational Culture } \rightarrow \\
\text { Employee Engagement }\end{array}$ & 0.640 & 0.636 & 0.125 & 5.127 & $\mathbf{0 . 0 0 0}$ \\
\hline $\begin{array}{l}\text { Organizational Culture } \rightarrow \\
\text { Work Attitude }\end{array}$ & .894 & 0.896 & 0.020 & 44.303 & $\mathbf{0 . 0 0 0}$ \\
\hline $\begin{array}{l}\text { Work Attitude } \rightarrow \text { Employee } \\
\text { Engagement }\end{array}$ & 0.274 & 0.278 & 0.129 & 2.116 & $\mathbf{0 . 0 3 5}$ \\
\hline
\end{tabular}

1. Organizational Culture has a direct positive and significant effect on Employee Engagement at PT Sapta Sentosa Jaya Abadi, this is indicated by a significance value of $0.000<0.050$ so that H1-1 is accepted.

2. Organizational Culture has a direct positive and significant effect on Work Attitudes at PT Sapta Sentosa Jaya Abadi, this is indicated by a significance value of $0.000<0.050$ so that H1-2 is accepted.

3. Work Attitude has a direct positive and significant effect on Employee Engagement at PT Sapta Sentosa Jaya Abadi, this is indicated by a significance value of $0.035<0.050$ so that H1-3 is accepted.

Table 2. Indirect Effect

\begin{tabular}{|c|c|c|c|c|c|}
\hline & $\begin{array}{c}\text { Original } \\
\text { Sample } \\
(\mathbf{O})\end{array}$ & $\begin{array}{c}\text { Sample } \\
\text { Mean (M) }\end{array}$ & $\begin{array}{c}\text { Standard } \\
\text { Deviation } \\
\text { (STDEV) }\end{array}$ & $\begin{array}{c}\text { T Statistics } \\
(\text { (OO/STDEV|) }\end{array}$ & P Values \\
\hline $\begin{array}{c}\text { Organizational Culture } \rightarrow \\
\text { Work Attitude } \rightarrow \text { Employee } \\
\text { Engagement }\end{array}$ & 0.245 & 0.250 & 0.117 & 2.091 & 0.037 \\
\hline
\end{tabular}

Based on the data in the table above, it is obtained indirectly by proving the hypothesis that Organizational Culture has a positive and significant effect on Employee Engagement through Work Attitudes at PT Sapta Sentosa Jaya Abadi, this is indicated by a significance value of $0.037<0.050$ so H1-4 is accepted.

\section{Determination Test $\left(\mathbf{R}^{2}\right)$}

Table 3. R Square

\begin{tabular}{|l|r|r|}
\hline & \multicolumn{1}{|c|}{ R Square } & \multicolumn{1}{|c|}{$\begin{array}{c}\text { Adjusted R } \\
\text { Square }\end{array}$} \\
\hline Employee Engagement & .798 & .793 \\
Work Attitude & .800 & .797 \\
\hline
\end{tabular}

The variable of Organizational Culture through Work Attitudes contributed $79.8 \%$ to the formation of Employee Engagement at PT Sapta Sentosa Jaya Abadi in this study, the remaining 20.2\% was influenced by other factors not measured in this study.

Research conducted by Primasheila, et al (2017) shows that a positive organizational culture is able to form a satisfied work attitude towards the results of his work. This shows that a positive organizational culture is able to produce work attitudes, where work attitudes are predictors of Employee Engagement. This then underlies the author to include Work Attitudes as a mediating variable, assuming the effect of forming employee engagement will be better if through the formation of work attitudes. However, the results of the study found that the correlation coefficient of the direct influence of Organizational Culture on Employee Engagement is 0.640 while the correlation coefficient of the indirect influence of Organizational Culture 
Irwanto Sahat Wijaya Sibagariang et.al. The role of organizational culture in establishing employee engagement through work attitude at PT. Sapta Sentosa Jaya Abadi.

through Work Attitudes on Employee Engagement is 0.245 . This actually shows that the formation of employee engagement is greater without Work Attitude intervention. This is possible at PT Sapta Sentosa Jaya Abadi because employees consider work attitudes as part of Employee Engagement, so their assumptions between Work Attitudes and Employee Engagement are the same. This can be seen from the average score between Work Attitudes (3.36) not much different from Employee Engagement (3.37). This is a weakness in this study, which chose the mediating variable to have a less significant role in the formation of Employee Engagement at PT Sapta Sentosa Jaya Abadi.

\section{CONCLUSION}

1. Organizational Culture is directly proven to have a positive and significant effect on Work Attitudes at PT Sapta Sentosa Jaya Abadi.

2. Organizational Culture has a direct positive and significant effect on Employee Engagement at PT Sapta Sentosa Jaya Abadi.

3. Work Attitude is directly proven to have a positive and significant effect on Employee Engagement at PT Sapta Sentosa Jaya Abadi.

4. Organizational Culture through Work Attitudes is indirectly proven to have a positive and significant effect on Employee Engagement at PT Sapta Sentosa Jaya Abadi.

\section{Acknowledgement: None}

\section{Conflict of Interest: None}

\section{Source of Funding: None}

\section{REFERENCES}

1. Armstrong, Michael. (2014). Armstrong's Handbook of Human Resource Management Practice, 13th Edition. KoganPage.

2. Brenyah, Richard S. dan Theresa ObuobisaDarko. (2017). Organisational Culture and Employee Engagement within the Ghanaian Public Sector. Review of Public
Administration and Management. Vol. V, No. 3, Hal. 1 - 7 .

3. Duha, Timotius. (2018). Perilaku Organisasi. Jakarta: Penerbit Deepublish.

4. Gallup. (2017). State of the Global Workplace. Gallup Press.

5. Kaswan, Akhyadi. (2015). Pengembangan Sumber Daya Manusia. Bandung: Penerbit Alfabeta.

6. Noe, Raymond A, Hodlenback, John R., Gerhart, Barry., dan Wright, Patrick M. (2014). Fundamentals of Human Resource Management, 6th Edition. McGraw-Hill Education.

7. Pieters, Wesley R., Ebben van Zyl dan Petrus Nel. (2019). Job Attitudes as a Predictor of Work Engagement of the Lecturing Staff at the University of Namibia. SA Journal of Human Resource Management. Vol. XVII, No. 1, Hal. 1 - 11.

8. Prahara, Sowanya Ardi dan Syarif Hidayat. (2019). Budaya Organisasi Dengan Work Engagement pada Karyawan. Jurnal RAP (Riset Aktual Psikologi), Universitas Negeri Padang, Indonesia. Vol. X, No. 2, Hal. 232 $-244$.

9. Primasheila, Debitri, Agustina Hanafi, dan Supardi A. Bakri. (2017). Pengaruh Budaya Organisasi Terhadap Kepuasan Kerja Karyawan PT. Telkom Kantor Wilayah Palembang. JEMBATAN - Jurnal Ilmiah Manajemen Bisnis dan Terapan, Universitas Sriwijaya, Palembang. Vol. XIV, No. 1, Hal. 25 - 32.

10. Robbins, Stephen P., Timothy A. Judge dan Katherine E. Breward (2018). Essential of Organizational Behaviour, Canadian Edition. Pearson.

11. Schermerhorn, John R., Hunt, James G., Osborn, Richard N., Uhl-Bien, Mary. (2010). Organizational Behavior, 11th Edition. John Wiley \& Sonns, Inc.

12. Sinulingga, Sukarya. (2017). Metodologi Penelitian. Medan: Universitas Sumatera Utara Press.

13. Steven, Juda dan Unika Prihatsanti. (2017). Hubungan Antara Resiliensi Dengan Work Engagement Pada Karyawan Bank Panin Cabang Menara Imperium Kuningan Jakarta. Jurnal Empati, Universitas Diponegoro, Semarang. Vol. VII, No. 3, Hal. 160 - 169.

14. Sugiyono. (2017). Statistika untuk Penelitian, Cetakan XIX. Bandung: Penerbit Alfabeta. 
Irwanto Sahat Wijaya Sibagariang et.al. The role of organizational culture in establishing employee engagement through work attitude at PT. Sapta Sentosa Jaya Abadi.

15. Supartha, Wayan Gede dan Desak Ketut Sintaasih. (2017). Pengantar Perilaku Organisasi, Teori, Kasus dan Aplikasi Penelitian. Denpasar: CV. Setia Bakti.

16. Werner, Havenga, Stanz Karel dan Visagie Jan. (2011). Evaluating the difference in employee engagement before and after business and cultural transformation interventions. African Journal of Business Management. Vol. V, No. 22, Hal. 8804 8820.

17. Widarjono, Agus. (2015). Analisis Multivariat Terapan, Edisi Kedua. Yogyakarta: UPP STIM YKPN.

18. Yusof, Hani Sakina Mohamad, Rudzi Munap, Muhammad Izwan Mohd Badrillah,
Noor Raihan Ab Hamid, Romiza Md Khir. (2017). The Relationship Between Organizational Culture and Employee Motivation as Moderated by Work Attitude. Journal of Administrative and Business Studies, TAF Publishing, Malaysia. Vol. III, No. 1, Hal. 21 - 25.

How to cite this article: Sibagariang ISW, Absah Y, Sadalia I. The role of organizational culture in establishing employee engagement through work attitude at PT. Sapta Sentosa Jaya Abadi. International Journal of Research and Review. 2021; 8(11): 476-481. DOI: https://doi. org/10.52403/ijrr.20211160 